\title{
HOLY TIME AND POPULAR INVENTED RITUALS IN ISLAM Structures and Symbolism
}

\author{
Mabrouk Chibani Mansouri
}

Sultan Qaboos University, Muscat, Oman

email:mabroukmansouri@squ.edu.om

\section{Abstract}

This paper tackles three popular invented rituals in the early centuries of Islam performed in the seventh and eighth months of the Islamic calendar; Rajab and Shacbain, namely the sacrifices of fara' $a$ and 'atira, fasting and prayers. In the light of sociocultural and psycho-cultural perspectives, the paper discusses the cultural and spiritual perceptions of time and space in Islam, and the reasons that make specific settings fertile soils suitable for inventing new rituals. Then, it analyzes the structures and symbolism of these rituals as a means of dialogical relationship with the self, the other, and the group. The paper also sheds light on the piety folk developed by Sufism as a response to spiritual void and psychological needs that lead Muslims to invent new forms of worship. The paper will, then, analyze the scholarly debate over the legitimacy of these invented rituals and the festivities associated with them, and tackle the interpretative strategies to approve them in a long dialectical process with 'puritan' Muslims. In the end, it discusses the relationship of invented rituals to the embedded structure of power and it sheds light on the reasons behind the escalation of practicing these invented rituals in recent decades in the Arab Islamic world.

Tulisan ini mengkaji tiga ritus ibadah di awal abad perkembangan Islam yaitu perayaan bulan Rajab dan Sba'ban, Farda dan 'Atira, puasa dan shalat. Dengan pendekatan sosial budaya dan psikologi budaya, tulisan ini membahas persepsi budaya dan spiritual mengenai waktu dan ruang dalam Islam, serta 
menjelaskan setting khusus yang membuat reka cipta ritual baru. Disamping itu tulisan ini juga membahas struktur dan simbol ritual teresebut sebagai perangkat dialog dengan diri sendiri, pibak lain dan kelompok. Tulisan ini juga membahas pengembangan bentuk. kesalehan kaum sufi sebagai respon kebutuban psikologis dan pemenuhan spiritual yang menuntun umat muslim mereka cipta bentuk persembahan baru. Termasuk perdebatan para ulama mengenai legitimasi perayaan tersebut dan proses dialog dengan kelompok puritan. Di bagian akbir akan dijelaskan hubungan ritual tersebut dengan struktur kekuasaan yang melekat dan menguatnya praktik tersebut beberapa dekade terakbir terutama di dunia muslim Arab.]

Keywords: Popular Culture, Invented rituals, Sacrifices, Fasting, Prayer, Rajab, Shacbàn.

\section{A. Introduction}

Studies of Islamic popular rituals are relatively limited in number and scope. ${ }^{1}$ Despite the dynamics of popular culture in Muslim societies, which assumes similar functions in many religions, ${ }^{2}$ it still needs further sociocultural and historical academic scrutiny. ${ }^{3}$ One of the obstacles facing studies of popular culture in Islam is the heavy burden of Colonial Orientalism ${ }^{4}$ and colonial anthropology, ${ }^{5}$ which challenged the essence of mainstream Islam and inflamed the ethno-sectarian conflict in Islamic world their proponents said. Moreover, these studies confronted the classical Islamic scholarships, which classified any invented rituals or popular religious practice in Islam as a heresy (bid'a); any "bid'a, they argue, are misguided (Kullu bid'a dhaläla) and will lead Muslims to Hell

1 Karin van Nieuwkerk, Mark LeVine, and Martin Stokes (eds.), Islam and Popular Culture (Austin: University of Texas Press, 2016), p. 1.

2 Jean Jacques. Waardenburg and P.H. Vrijhof (eds.), Official and Popular Religion: Analysis of a Theme for Religious Studies (The Hague: Mouton, 1979).

3 Marshall G.S. Hodgson, The Venture of Islam: Conscience and History in a World Civilization (Chicago: University of Chicago Press, 1974); Clifford Geertz, Islam Observed: Religious Development in Morocco and Indonesia (Chicago: University of Chicago Press, 1971).

${ }^{4}$ Edward W. Said, Orientalism (New York: Pantheon Books, 1978).

5 Talal Asad (ed.), Anthropology \& the Colonial Encounter (Amherst, NY: Humanity Books, 1973). 
(Kullu dhaläla fi an-när)". ${ }^{6}$ Consequently, any invented ritual is a deviation from the 'true' religion, a reprehensible heretical practice, as "Muslims are not allowed to add or reduce Islamic teachings and rituals. Rituals must be based on the main sources of Islam and any religious innovation is considered bid'a". ${ }^{7}$ One of the primary tasks of this 'puritanizing' tendency led by medieval Muslim scholars is eliminating any belief or practice that strays beyond the constraints of the primary sources of religion, classifying any popular religious practices as inventions comprising contaminating borrowings from religions other than Islam, mainly paganism and ancient Persian practices.

Such a vision, according to Talal Asad, is related to the realm of orthodoxy, as a body of opinions and as a relationship of power; "Wherever Muslims have the power to regulate, uphold, require, or adjust correct practices, and to condemn, exclude, undermine, or replace incorrect ones, there is the domain of orthodoxy". ${ }^{8}$ A sense of puritanism arose among Muslim scholars in their endeavor to 'purify' Islam from any deviation from the strict teachings of the Quran and Sunna. Thus, "folk customs become sources of religious innovations (bid' $a$ ) and superstitions (khuräfät) which contaminate Islamic teachings by adding or reducing religious rituals or beliefs". ${ }^{9}$ For other scholars, however, these rituals are not heretical as they preserve the fundamentals of religion and the essence of Islam; they have strong textual and historical basis embedded in the referential experience of the Prophet and the early generations of his companions.

This paper discusses the structure and symbolism of invented rituals in Islam, namely the popular sacrifices of fara' $a$ and 'atira, invented fasting and prayers in the seventh and eighth months of the Islamic calendar; Rajab and Sha'bān. Despite being invented, these rituals have preserved the acknowledged structure of Islamic worship. They are invented either regarding the popular perception of time they are practiced in, or times

6 Ahmad Bunyan Wahib, "Being Pious Among Indonesian Salafists", Al-Jami'ah: Journal of Islamic Studies, vol. 55, no. 1 (2017), pp. 1-26.

7 Ibid., p. 8.

8 Talal Asad, The Idea of an Anthropology of Islam (Washington: Center for Contemporary Arab Studies, Georgetown University, 1986), p. 15.

9 Wahib, "Being Pious Among Indonesian Salafists", p. 10. 
they are practiced for. The controversy concerning the legitimacy of the invented prayer of wishes (raghäib) centered around the holiness of the time in which it was established; the eve of mid-Rajab, the number of rake $a$ this prayer is consisted of, and the recitation of specific Quran chapters for several times in each $r_{k}{ }^{c} a$.

Consequently, these invented popular rituals, in this perspective, are popular establishments of religion guided by rules from the received religious system; they are innovations from within the system, not a subversion of the religious status quo. However, they reflect a popular sacralization of time and space in Islam and the festivities associated with them embody 'profane' elements expressive of sociocultural needs.

The paper claims that the phenomenon of popular invented rituals in Islam, and the sociocultural festivities associated with them, encompass a structural and symbolic 'complex-whole' that necessitates looking at them from different psychological, anthropological and sociocultural perspectives. Following Clifford Geertz analysis, these rituals are symbolic systems through which people create private and collective meaning-systems that echo values, perceptions, and ambitions. ${ }^{10}$ The sociocultural perspective suggests that rituals are expressions of individual and group's correlated relations as semantic tools through which individuals and groups reassure and strengthen their link to the community of believers to which they belong. They provide them with channels through which people communicate inner and outer emotions and perceptions with their selves, their communities, and their God, and respond to the mysteries of life.

People create new forms of worship, in this regard, to toughen their multi-fold relations to their spiritual and social realms. The psychocultural perspective suggests that invented rituals in Islam are significant experiences of feeling identified with the divine, rather than nominal act typifying official forms of worship. Invented rituals, in this regard, embody sets of psycho-social components organizing private and collective experiences. Humans, according to A. Baucal and T. Zittoun, "can be quite creative in their uses of religious resources, which can lead them to transform their own actions, meaning making, and relationship

${ }^{10}$ Clifford Geertz, "Religion as a Cultural System", in Anthropological Approaches to the Study of Religion, ed. by Michael Banton (London: Routledge, 2004). 
with others". ${ }^{11}$ Moreover, the paper takes into consideration the historical and cultural context in which these new rituals were invented, and the psycho-cultural motivations, interpersonal, and collective dynamics that led to their invention. Textual and contextual analysis of assumptions and implications of invented ritual in Islam is revealing in this context.

Consequently, "religion, as a cultural and symbolic system, participates to the orchestration of human activities and sense-making. Such orchestration works both from within the person, through internalized values and ideas, and from without, through the person's interactions with others, discourses, cultural objects etc". ${ }^{12}$ Popular rituals, in this regard, echo a multi-fold dialogue of sociocultural nature within the individual, with the groups, and with the divine realm, echoing private and collective imaginaries, inherited cultural forms, and perceptions of different ethnic groups that belonged to medieval Islamic settings and enriched its culture.

Following A. Baucal and T. Zittoun analysis of "religion as a dialogical resource", and their model of three forms of dialogue that religion can perform, the socio-cultural approach suggests that invented rituals in Islam can refer to:

- Dialogue with the self: Religion is «a self-chosen orchestration of one's life, supporting a sense of personal continuity through time and situations and a sense of value and purpose». ${ }^{13}$ While ordinary Muslims see time and space as holy models that could be filled with new rituals, as an act of piety and as a response to spiritual and sociocultural needs, 'puritan' Muslims look at them as a deviation from the true religion. One of the challenging themes that this paper will address is why specifically individuals consider the seventh and eighth months of the Islamic calendar the suitable holy times for communicating and dialogizing their spiritual needs through inventing new rituals. What symbolism both months bear in the individual imaginary and perception of the holiness of time in Islam.

11 Aleksandar Baucal and Tania Zittoun, "Religion as Dialogical Resource: A Socio-cultural Approach", Integrative Psychological and Behavioral Science, vol. 47, no. 2 (2013), p. 218.

$\begin{array}{ll}12 & \text { Ibid., p. } 207 . \\ 13 & \text { Ibid., p. } 213 .\end{array}$ 
- Dialogue with a distant or imaginary other: Religion is a channel through which the individual and the group establish a dialogical relationship with a transcendent Other. As a means to strengthen their attachment to the realm of God, and to assure His satisfaction, medieval Muslims invented new prayers, fasting, and sacrifices. Moreover, religious rituals and the festivities associated with them are symbolic tools that can establish spiritual and psychological representations of, and dialogue with the absent other, mainly through celebrating the Prophet's nativity and the religious leader's commemoration.

- Dialogue Within Groups: With reference to the Greco-Roman etymology of the term 'religion', which suggests the idea of linking, A. Baucal and T. Zittoun inferred that religion performs a linking function of the self to others. Islam, etymologically, refers to submission. The semantics of submission can also be interpreted as a form of dialogue within the group, as individuals submit themselves to God, and to the community of believers. Consequently, various levels of dialogue are performed. As Van Gennep showed ${ }^{14}$, religious rituals, in this regard, are means to reevaluate and strengthen one's belonging to his ethnoreligious group, and to the wide community of believers. These rituals request consistently shared activities, festivity, frequently with compelling enthusiastic ramifications. Their collective celebration establishes relational recollections that need to be interpreted with reference to its sociocultural setting. Moreover, popular invented rituals may enhance the submissive function to the ruler; and, thus, they become tools of political empowerment. Marion Holmes Katz's 'royal audience model of prayer' is significant in this regard. ${ }^{15}$ Muslim rulers, as will be discussed later, felt the importance of these invented rituals and the congregations related to them. As such, they employed them in enhancing the value of submission to God, and thus, to the ruler, as His earthly deputy (khalifa). Consequently, Muslim rulers supported these popular invented rituals, underestimated official

14 Arnold van Gennep, The Rites of Passage (Chicago: University Of Chicago Press, 1972).

15 Marion Holmes Katz, Prayer in Islamic Thought and Practice (Cambridge: Cambridge University Press, 2013), pp. 92-102. 
scholars reaction over them, and compelled some of them to issue fatwas in their favor.

In examining these invented rituals and the festivities associated with them, the current work estimates that they represent a 'collective cultural reservoir'; 'complex whole' that encompasses various meaning systems and worldviews reflecting the spiritual, psychological, and social needs of different ethnic and cultural groups that adopted Islam and enriched its popular culture. ${ }^{16}$

\section{B. Holy time in Islam and the sanctification of Rajab and Shacbān}

The seventh and eighth months of the pre-Islamic Arabian calendar; Rajab and Shacbān, were praised (al-ashbur al-burum) for interrelated sanctimonious, cultural, and social reasons, ${ }^{17}$ in which three rituals were practiced: fasting (sawm), slaughtering (nabrr), and pilgrimage (bajj). Etymologically, Rajab derives from a Semitic root that refers to the act of consecration and glorification. The verb tarjib means to glorify and sanctify someone or something. ${ }^{18}$ Sha $c b a n n$ etymologically derives from Rajab; literally, tashacaba minhu. Consequently, they were called 'twin months' (al-rajabayn), sharing a specific holy status compared to other months.

The continuity of their glorification in Islamic popular culture is grounded in pre-Islamic perceptions of time, after being adjusted to the requirement of the new religion and responded to the psychological and spiritual horizons of popular Muslims. Consequently, the lunar months of Rajab and Shacbann have been deemed the suitable holy time for most invented rituals in Islam. ${ }^{19}$ Both months were expressive of various

16 Jacques Waardenburg, "Official and Popular Religion in Islam”:, Social Compass, vol. 25, nos. 3-4 (1978), pp. 315-41; Jean Jacques. Waardenburg and P.H. Vrijhof (eds.), Official and Popular Religion: Analysis of a Theme for Religious Studies (The Hague: Mouton, 1979), pp. 313-41.

${ }^{17}$ Ismāīll Ibn Kathīr, Tafsìr Al-qur'ān, vol. 4, ed. by Sami Salamah (Beirut: Tayba, 1999), p. 148.

18 Muhammad ibn Aḥmad Azhurī, Tahdhīb al-Lughah, vol. 2, ed. by Maḥmūd (Egypt: Misriyya), p. 53.

19 Muhammad Ibn-al-Walīd aț-Ṭurțūšī, Kitāb al- ḥawādit' wa-l-bidac, ed. by María Isabel Fierro (Madrid: Consejo Superior de Investigaciones Científ., Inst. de Cooperación con el Mundo Árabe, 1993); M.J. Kister, "Sha'bān Is My Month...: A Study of an Early 
cultural, spiritual, and symbolic connotations. In fact, in addition to preIslamic Arabs, Jews, Babylonians ${ }^{20}$, and Amazigh ${ }^{21}$ considered Rajab, as the month of 'purification and penance' and celebrated its rituals in the spring. ${ }^{22}$

The magnitude of the reverence for the month of Rajab in pre-Islamic Arabia was reflected in its numberless names, each of which summarizes correlated religious and cultural settings. ${ }^{23}$ With Șüfism, however, tarjīb shifted to adoring and rehashing Allah's names. Subsequently, it becomes a pattern of discourse based on the countless reiteration of the Holy Names. Al-Jaylānī (d. 561 H/1166 AD) claimed that holy angels raise their voices in acclaim, appreciation, and sanctification towards God in Rajab. ${ }^{24}$ For him, Rajab is called (al-asab) because "God pours mercy on people in abundance and He offers them outstanding dignity and incomparable recompense". ${ }^{25}$ Ibn Manzūr concurred with this new sense of the term, admitting that this month

Tradition", in Studia Orientalia Memoriae D.H.Baneth Dedicate (Jerusalem: The Magnes Press \& Institute of Asian and African Studies, 1979), pp. 63-70; M.J. Kister, "Rajab Is the Month of God.' A Study in the Persistence of an Early Tradition", in Studies in Jabiliyya and Early Islam (London: Variorum, 1980), pp. 191-223.

20 Shelomo Dov Goitein, Studies in Islamic History and Institutions (Leiden: Brill, 2010), p. 93.

21 Abd al-'Azīz Bakrī, Al-Masālike wa al-Mamālike, vol. 2, ed. by Van Lioven and Feery (Tunisia: Al- 'Arabiyya, 1968), p. 824; Muhammad Ibn 'Idhārī, al-Bayān al-Mugrib, vol. 1, ed. by G.S. Colin and Evariste Lévi-Provençal (Beirut: Dār al-Thaqāaah, 1967), p. 226; Ibn Khaldūn, Kitāb al-'Tbar, vol. 4 (Beirut: Dār al-Kitāb al-Lubnānī, 1979), p. 428; María Isabel Fierro Bello, Heterodoxia en al-Andalus Durante el Periodo Omeya (Madrid: Instituto Hispano-Árabe de Cultura, 1987), p. 157.

22 As a solution for the difference between the solar calendar and the lunar one, pre-Islamic Arabs used to add a month to the calendar from time to time. It was called the 'intercalated month'. Jews do the same seven times in every nineteen years. Islam abrogated this intercalation (Quran, 9:37). As a result, Islamic Lunar months are not related to specific seasons as was the case in the Jäbiliyya when Rajab and Sha'bān were spring months.

23 Aḥmad ibn 'Alī Ibn Hajar al-'Asqalānī, Tabyinn al-'ajab bimā warada fì fạlli Rajab (Miṣr: Maktabat 'Abd al-Wāḥid al-Tāzī, 1932), pp. 1-3; Ibn Manzūur, Lisān al-'A rab, vol. 1 (Cairo: Dār al-Ṣāwī lil-Ṭab“ wa-al-Nashr wa-al-Ta”līf, 2003), p. 124.

24 Abd. Al-Qadir Al-Jaylani, Al-ghunyah li talibi tariq al-haq 'az wa jal, vol. 1 (Beirut: Dar al-Kotob al-'IImiyah, 2003), pp. 173-4.

25 Ibid., vol. 1, p. 175. 
is the holiest month of divine response to supplications, invocations, and needs, even much more than Ramadhan. ${ }^{26}$ This new perception of time compared the superiority of Rajab over other months to that of the Quran over other speech, or to that of God over all His creatures. ${ }^{27}$ Sufis bolstered this vision by a hadith reported on the authority of Ibn 'Abbās, in which God told Moses:

O, Moses! I made Rajab a holy month (Shahr ḩarām) and I called it al-asabb (the pouring) because I countlessly pour mercy in it. In this month, I open the heavens' doors [with mercy] and I pour My blessings. O, Moses! There is a day in which I divide the creatures' livelihoods, which is the day of mid-Rajab. O, Moses! Remember Me [in that day] and I remember you in My Majesty. O, Moses! My Angels pray for him who supplicates in that day. ${ }^{28}$

The pre-Islamic sanctification of both months was associated with complex cultural settings entailing religious, social, and symbolic dimensions. However, in Islam Ramadān was chosen as the holy month of fasting, whereas Rajab and Shacban remained void of official Islamic rituals. The continuity of time holiness in Arab Islamic culture made Rajab and Shacbān fertile soils for inventing new rituals such as fasting and prayers, while other pre-Islamic rituals continued to be practiced in the early centuries of Islam after being entirely or partially adjusted to the fundamental requirements of the new religion. ${ }^{29}$

A religious debate rose among medieval scholars over the holiness of both months in Islam. 'Puritan' scholars insisted that "The Jäbiliyya people revered Rajab. When Islam came, it was left behind". 30

26 Manẓūr, Lisān al-`Arab, vol. 1, p. 124.

27 Muhammad b. Muhammad al-Wazīr al-Andalusī, al-Hulal al-sundusiyya fì alakbār al-Tūnisiyya, vol. 1, ed. by Muḥammad al-Hạīib al-Hīla (Beirut: Al-gharb al-islāmī, 1985), pp. 188-9.

28 Muhammad b. Muhammad al-Wazīr al-Andalusī, al-Hulal al-sundusiyya fì alak'bār al-Tünisiyya, vol. 3, ed. by Muḥammad al-Habīb al-Hīla (Beirut: Al-gharb al-islāmī, 1985), p. 204. (All original Arabic translations are mine unless stated otherwise).

29 Kister, “'Sha'bān Is My Month...': A Study of an Early Tradition”, pp. 15-37; Kister, "Rajab Is the Month of God.' A Study in the Persistence of an Early Tradition", pp. 192-223.

30 Nūr al-Dīn 'Alī ibn Abī Bakr Haythamī, Majma' al-zawä̀id wa-manba' al-fawä̀id, vol. 3 (Beirut: Al-Kitāb al-Lubnānī, 1967), p. 191. 
Consequently, all popular rituals have been classified as 'reprehensible innovations'. A full literature of refutation against heresies was classified such as Kitāb al-Bidá wa al-hawädith of al-Ṭurțūshī (d. 520 H/ 1126 AD) and al-Bäith 'alà inkēr al-bida wa al-hawàdith of Abū Shāma (d. $665 \mathrm{H}$ / 1267 AD). Moreover, books of unauthentic hadiths (mawdiūat) devoted specific chapters for the hadiths of Rajab and Shacban, such as Kitäb al-

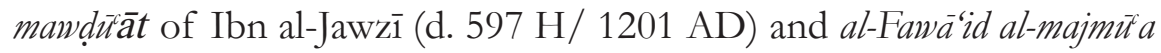
of al-Shawakānī (d. 1255 H/ 1839 AD). Later scholars dispensed full works for the innovated forms of worship in Rajab and Shacban, such as Tabyin al-'ajab bimà warada fì shahri Rajab of Ibn Hajar (d. 852 H/ 1448

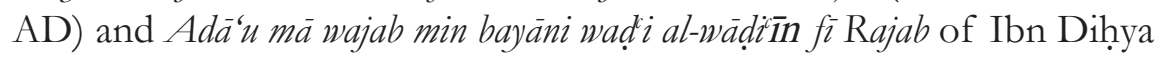
(d. $633 \mathrm{H} / 1236 \mathrm{AD})$.

By contrast, Șūfĩ scholars considered that "Rajab is a glorified month in the Jäbiliyya. In Islam, it acquired more glorification". ${ }^{31}$ Shī' 1 sources also adopted this view concerning the glorification of Rajab verbatim. ${ }^{32}$ Works, such as Qüt al-quī̄b of al-Makkī (d. 386 H/ 996 AD), Ibya ' 'ulum al-dìn of al-Ghazālì (d. 505H/1111 AD), and al-Ghunya of al-Jaylānī (d. 561 H/1166 AD), approved the invented rituals of both months and supported them by hadiths attributed to Prophet Muhammad such as: "Rajab is the month of God, Shacbān is my month, and Ramadann is the month of my people". ${ }^{33}$ Although the former group of scholars attempted to diminish the sanctity of Rajab and Shacban and the rituals associated with them, both months maintained their glorification in popular Islam, and popular Muslims have largely practiced their rituals, mainly sacrifices, fasting and prayers, and continued to be practiced until nowadays.

31 Al-Jaylani, Al-ghunyah li talibi tariq al-haq 'az wa jal, vol. 1, pp. 176.

32 Muhammad ibn al-Hasan Fattal al-Nisaburi, Rawdat al-wä̈zin., vol. 2, ed. by Gh. Majīīī and M. Farjī̄ (Qum: Dalīl Mā, 1961), p. 310 no. 1235.

33 Al-Jaylani, Al-ghunyah li talibi tariq al-haq 'az wa jal, vol. 1, p. 192; Abū al-Faraj 'Abd al-Raḥmān ibn 'Alī Ibn al-Jawzī, Al-Mawdụ'àt, vol. 1 (Makkah: Al-Maktaba alSalafiyya, 1966), p. 125; 'Abd al-Raḥmān ibn Ismā'̄îl Abū Shāmah, al-Bā'ith 'alá inkērr al-bida' wa-al-ḩawädith (Beirut: al-Fikr, 1992), p. 64. In Shīcī sources, Ramaḍān-instead of Rajab-is the month attributed to God. See Fattal al-Nisaburi, Rawdat al-waïzin., vol. 2, pp. 319-20 no. 1242; 1244. 


\section{Popular sacrifices of Rajab and Sha ${ }^{c} b a ̄ n$}

Among the many rituals practiced in pre-Islamic Rajab and continued to be observed in Islam is the holy sacrifice (nabr), which is considered as one of the many synonyms of the term. ${ }^{34}$ Popular Muslims preserved two pre-Islamic slaughtering rituals, namely, 'atira and fara'a. Despite the scholarly debate over the legitimacy of both rituals, a flexible interpretative approach has grounded their continuity until recent decades, mainly in rural and Saharan areas.

'Atira is a pre-Islamic sacrifice practiced in the month of Rajab, from which it acquired one of its name: rajabiyya, a term admitted by Prophet Muhammad himself..$^{35}$ According to Ibn Manzūur, ${ }^{36}$ tarjīb which is a synonym of $t a^{c} t a \bar{r}$, refers specifically to the slaughtering ritual of this sacrifice in Rajab. The fara $a$ (firstlings of the flock) refers to the first born-camel when one's herd numbers one hundred. Pre-Islamic Arabs used to raise that camel with utmost care, ritually slaughter it for their idols during the month of Rajab and pour its blood on the idols' heads for the blessing. ${ }^{37}$ Both slaughtering rituals continued to be practiced by ordinary Muslims and were considered as a cultural trait full of sacrament and spirituality.

Some Muslim scholars acknowledged this popular ritual emphasizing that Prophet Muhammad and his Companions, such as Ibn Sīrin (d. 110 H/729 AD), used to observe the 'atira in Rajab and approved its legitimacy. ${ }^{38}$ This group of scholars supported this view by a hadith reported on the authority of Mikhnaf Ibn Sulaym (d. 64 H/ 684 AD). "We were standing with the Prophet Muhammad, Peace Be Upon Him, in 'Arafa so I heard him saying: O, people! Every year, every householder should slaughter an udbiya and a 'atira. Do you know what

34 Azhurī, Tahdhìb al-lughah, vol. 2, p. 53.

35 Majd al-Dīn al-Mubārak ibn Muḥammad Ibn al-Athīr, al-Nihāya fì gharīb al-ḥadìth wa-al-athar., vol. 2, ed. by A. Zāwī and M. Ṭanāḥī, (Cairo: Dār Iḥyā̄ al-Kutub al-cArabiyya, 1963), p. 197.

36 Manẓūr, Lisān al-'Arab, vol. 1, p. 124.

37 Majd al-Dīn al-Mubārak ibn Muḥammad Ibn al-Athīr, al-Nihāya fì gharīb al-ḥadìth wa-al-athar., vol. 3, ed. by A. Zāwī and M. Ṭanāḥī, (Cairo: Dār Iḥyā' al-Kutub al-cArabiyya, 1963), pp. 435-6.

38 Muhammad Shams al-Haqq 'Azūimābādī, 'Awn al-ma'būd: sharh Sunan Abì Dāwūd, vol. 6 (Madinah: al-Maktabah al-Salafiyah, 1968), p. 244. 
a 'atira is? It is what you call rajabiya". ${ }^{39}$ However, 'puritan' scholars used the concept of abrogation to contest this popular ritual. For them, in addition to being "a strange, of a weak chain of narrators (badith gharib dha'if al-isnād", ${ }^{40}$ this hadith was abrogated by another: "No fara' $a$ and no 'atira'" ${ }^{41}$ Consequently, Islam approved the 'atira for a given period before it was abolished. Al-Azhurī commented "The 'atìra is the rajabiya. It is a slaughtering ritual used to be practiced by the people of Jahbiliyya in Rajab as a blessing for their gods. It continued to be practiced during the early years of Islam. Then it was abrogated". ${ }^{42}$ Nevertheless, Hadith criticism techniques, such as authenticity and abrogation, have not fully resolved the issue of the religious legitimacy of this popular ritual. Authenticity criticism, as an Islamic science, related to the chain of narrators, whereas the abrogation (naskb) deals with content. Consequently, if the hadith is unauthentic, as al-Tabrīzi insisted on, then, the concept of abrogation approved by some scholars is debatable.

After a long dialectical process among Muslim scholars, and with regard to the widespread of this popular sacrifice, an interpretative compromise resulted from the combination of the two previous opinions, as a flexible strategy in dealing with Islamic popular ritual. It acknowledged that these slaughtering rituals are religiously legitimate after being Islamicized and 'purified' of their pagan connotations. Thus, the badith of Ibn Sulaym was admitted as authentic, not forged or weak, and the second hadith "No fara'a and no 'atira" was interpreted as indicating that both sacrifices are legitimate, but are not religiously compulsory. Al'Adhīm Abādī (d. 1329 H/ 1911 AD), summarized this view as follows:

Isḥāq Ibn Rāhawayh interpreted the hạadìth: 'No faraca and no catīra', as it

39 Muḥammad ibn 'Abd Allāh Khaṭīb al-Tibrīzī, Mishkeāt al-Mașābīh, vol. 1, ed. by A. Albānī (Damascus: al-Maktaba al-Islāmiyya), p. 456 no. 1478.

${ }^{40}$ Ibid., vol. 1, p. 465 . Worth to notice the significant difference between original texts and later copies. In an earlier manuscript of al-Azhurì's, Azhurī, Tahdhïb al-lughah, 2: 263., the word designating this ḩadith is așạ̣hu (righter than) instead of nāsikh (abrogator). Moreover, al-Tabrīzì misquoted al-Tirmidhîs classification of the Hadith as "a good, strange ḥadith (hadith ḥasan gharib)". Muhammad ibn 'Isa Tirmidhi, Al-Sunan, vol. 3, ed. by 'Uthmān (Beirut: Dar al-Fikr, 1983), p. 37 no. 1555.

41 Azhurī, Tahdhïb al-lughah, vol. 2, p. 262; al-Tibrīīi, Mishkēt al-Mașäbīh, vol. 1, p. 464 no. 1477; Tirmidhi, Al-Sunan, vol. 3, p. 34.

42 Azhurī, Tahdhïb al-lughah, vol. 2, p. 263. 
means: neither faraca nor catīra is compulsory. Al-Shāfi'ī said: there is no contradiction between the different narrated versions of this hadìth, as the meaning is: neither faraca nor catîra is compulsory. The Prophet, Peace Be Upon Him, meant by this negation: neither of them is compulsory. If this (interpretation) is correct, then the hadith negates it's being a Sunna, but it does not consider its practice as unlawful or reprehensible. So, if ever a man slaughtered a sacrifice in Rajab or slaughtered a little camel for his personal need or charity it is not reprehensible (laysa makrūhan). ${ }^{43}$

To support this opinion, scholars referred to the Tabaqät of Ibn $\mathrm{Sa}^{\mathrm{c}} \mathrm{d}$, in which he mentioned that the Prophet was asked about the fara' $a$ and 'atira in the Last Prophetic Sermon (kbutbat al-wada't the last Prophetic religious orders and commands). The Prophet let it free according to the will of the Muslim. ${ }^{44}$ If the Prophetic speech concerning these slaughtering rituals was surely pronounced in the Last Sermon, and it seems to be, then the application of the concept of abrogation is debatable. Moreover, Al- ${ }^{c}$ Ażìm Abādī narrated others ḥadiths on the authority of ' $\bar{A}$ 'isha and Nubaysha al-Hudhali (alive in 11 H/ 632 AD) legitimizing these rituals, and he noticed that the sayings of ' $\bar{A}$ ' isha and Nubaysha are beyond doubt, ${ }^{45}$ and so did Ibn al-Athìr. ${ }^{46}$ This is, in his view, the adequate interpretation, as it suits the fundamentals of religion, and contradicts the pre-Islamic slaughtering for the sake of the idols. ${ }^{47}$

This interpretative tendency ensures the legitimacy of these popular slaughtering rituals after being 'purified' of their pre-Islamic perceptions and connotations. Popular Muslims continued to practice them while their framing concepts and their religious connotations changed. The animals were no longer slaughtered for idols, but for Allah as an act of blessing and charity. Linguistically, the signifier remained the same whereas the sign was changed. Anthropologically speaking, rituals may witness total or partial shifts in structure or symbolism for pressure of official culture, and, thus "religious systems are regulated by institutions which precisely

\footnotetext{
43 'Aẓ̌imābādī', 'Awn al-ma'būd, vol. 6, p. 244.

44 Muḥammad Ibn-Sa'd, Al-Ṭabaqāt, vol. 7 (Beirut: Al-kitāb al-lubnānī, 1957),
} p. 64.

45 'Azịimābādī, 'Awn al-ma'būd, vol. 6, p. 244.

46 Ibn al-Athīr, al-Nihāya fi gharīb al-ḥadith wa-al-athar., vol. 3, p. 178.

47 Ibid. 
attempt to constrain the variability of these dialogical and interpretative processes". ${ }^{48}$ It is as a strategy of adjustment to fulfill the psycho-cultural needs of popular Muslims and at the same time preserve its distinctive trait as being religious.

Indeed, the holy sacrifices of fara'a and 'atira go beyond the phenomenal act of charity and blessings; they are sociocultural rites full of expressivity and symbolism, on one hand, and collective acts that embedded a vision of time, space and things on the other. These religious sacrifices are used as symbolic resources to engage in sociocultural practices that "support one's sense of continuity, maintain one's sense of belonging, regulate one's relationship with others". ${ }^{49}$ The festivities associated with these popular rituals of slaughtering may refer to intrinsic and extrinsic feelings that a person can dialogize with himself, the community of believers through preserving and participating these rituals. Official institutions, including the bodies who claim to represent it and feel to have the right to produce knowledge, interpret it, and protect the system of meaning from 'any stray beyond the limits', failed in eliminating these sacrifices. However, as time went by, fara' $a$ and 'atira disappeared, owing to the significant shift in economic structures in the Arab-Islamic world.

\section{Invented Popular Fasting in Rajab and Shacbān}

Fasting, religiously and culturally, varies regarding duration and inconsumable items according to conditions that govern human groups. ${ }^{50}$ While collective rituals of sacrifices in Rajab, and the festivities associated with them express a socialization of the private and inner experience of religiosity, fasting, in itself, remains in the closed circle of privatization. Whoever, daylong divine chanting, Holy Names reciting, and fastbreaking, are collective manifestation by which the socialization of this

48 Baucal and Zittoun, "Religion as Dialogical Resource", p. 217.

49 Ibid., p. 212.

50 Robert Brunschvig, "Le culte et le temps dans l'islam classique", in Études d'islamologie, vol. 1 (Paris: G.-P. Maisonneuve et Larose, 1976), pp. 167-77; Shelomo Dov Goitein, "Ramadan, The Muslim Month Of Fasting, Its Early Development And Religious Meaning", in Studies in Islamic History and Institutions (Leiden: Brill, 1968), pp. 90-110. 
ritual is performed.

Fasting was a common practice in the Jäbiliyya, ${ }^{51}$ but sources on its regulations are missing. When Islam came, Ramadhan was chosen as the holy month of fasting. However, Islamic popular culture invented new forms of fasting in Rajab and Shacban due to the holiness of both months in the collective imaginary, insisting that it was a common ritual since the time of $\mathrm{Noah}^{52}$ as an invocation ritual or as a token of gratitude. ${ }^{53}$ Sunni, Súfí, and $\operatorname{Sh}_{1} \overline{1}^{54}$ sources listed many Prophetic Hadiths portraying the merits and divine reward of fasting during Rajab and Shacban. Regardless of their degree of authenticity, these Hadiths depict the strategies through which popular culture in Islam, which remained parallel to the official one, expresses Muslim perceptions, ambitions, and aspirations. One of the Hadiths attributed to Prophet Muhammad says:

Rajab is an excellent month in which God doubles the recompenses (hasanāt). He who fasts for one day in Rajab is as if he fasted the whole year. He who fasts for seven days in Rajab, seven doors of Hell will be closed in front of him. He who fasts for eight days, eight doors of Heaven will be opened to him. He who fasts for ten days he gets whatever he asks God. He who fasts for fifteen days he will hear a voice from the heavens: You are forgiven of your past deeds. Resume working, and God may give you bountifully. ${ }^{55}$

In another Hadith reported by al-Haythamī, God ordered Moses: "O, Moses! For him who fasts on the day of mid-Rajab, it is as if he performed one thousand admitted pilgrimages, and made one thousand

51 Goitein, "Ramadan, The Muslim Month Of Fasting, Its Early Development And Religious Meaning”, pp. 93-4; K. Wagtendonk, Fasting in the Koran (Leiden: E.J. Brill, 1968), pp. 29-40.

52 Al-Jaylani, Al-ghunyah li talibi tariq al-haq 'az, wa jal, 1: 175; Fattal al-Nisaburi, Rawdat al-waį̈in., vol. 2, p. 309 no. 1231; Haythamī, Majma' al-zawä̀id wa-manba' al-fawä̀id, vol. 3, pp. 188-91.

53 Al-Nawawī, Sharh Sahị̄h Muslim, vol. 8 (Cairo: Maṭbacat al-Hijāzī), p. 9; Yitzhak Nakash, "An Attempt To Trace the Origin of the Rituals of Āshurā ${ }_{s}$, Die Welt des Islams, vol. 33, no. 2 (1993), pp. 161-81.

54 Fattal al-Nisaburi, Rawdat al-waïzin., vol. 2, pp. 310-1 no. 1232-1235.

55 Haythamī, Majma' al-zawà'id wa-manba' al-fawä’id, 3: 191; Abū Bakr Ahmad ibn 'Alī Khaṭīb al-Baghdādī, Tarikh Baghdad., vol. 8 (Beirut: Dar al-Kitab al-'Arabi, 1966), p. 330 no. 4421. 
holy-invasions for the sake of God, and as if he released one thousand slaves for My sake". ${ }^{56}$ Sources mentioned that fasting on the mid-Sha ${ }^{c} b \bar{a} n$ is equal to fasting for 60 previous years and 60 following years. ${ }^{57} \mathrm{~A}$ badith indicated that "in heaven, there exists a river called Rajab. Its water is whiter than snow and sweeter than honey. He who fasts one day in Rajab may drink from it". ${ }^{58}$ Shī' 1 sources also reported this hadith on the authority of Jac far al-Șādiq. ${ }^{59}$

Official culture attempted to undermine this invented fasting. The second caliph Umar used to force people to break their fasting during Rajab, insisting that "Rajab was a revered month by Jäbilis. When Islam came, it was left behind". ${ }^{60}$ Despite these measures, fasting during Rajab has been deeply rooted in popular culture, as the most rewardable ritual in Islam. In addition to the Hereafter rewards mentioned in most Islamic sources, fasting shifts from being a private practice related to the inner experience of the individual, to being a collective ritual par excellence. Sufis have stressed two socializing rituals associated with fasting. The first is day long collective recitation of specific chapters of the Quran and Holy Names. ${ }^{61}$ The second is collective fast-breaking in mosques, Sufi shrines, and governors castles. Consequently, popular invented fasting, in addition to being humbly practiced, it exemplified a full set of inner and outer experience of the socialization of rituality in Islam. It echoed an orchestration of the sacred experience, in which all individuals can participate, regardless of age or sex, and dialogize their feelings and perceptions. Gradually, Muslim scholars tolerated its widespread practice.

56 Haythamī, Majma' al-zawä̀id wa-manba' al-fawà'id, vol. 3, p. 204.

${ }^{57}$ Ibn al-Jawzī, Al-Mawdèn'àt, vol. 1, p. 130.

${ }^{58}$ Muhammad Ibn al-Walīd Aț-Ṭurțūšī, Al-ḅawādit wa-ăl-bidac, ed. by 'Abd al-Maghīd Turkī (Beirut: Al-Gharb al-Islāmī, 1990), p. 272; Muḥammad ibn Aḥmad Dhahabī, Mì̃ān al-i'tidāl, vol. 4, ed. by 'Ali Muhammad Bajawi (Cairo: Dar Ihya' al-Kutub al-'Arabiyah, 1962), p. 189 no. 8797.

59 Fattal al-Nisaburi, Rawdat al-waïzin., vol. 2, p. 318 no. 1238.

${ }^{60}$ Haythamī, Majma' al-zawäid wa-manba' al-faw'̄id, vol. 3, p. 191.

61 Interestingly, reciting Holy Name and Attributes and Quran chapters in specific occasions is a joint celebration among Muslims in popular rituals all over the Muslim world, despite being considered as a heresy by strict scholars. Wahib, "Being Pious Among Indonesian Salafists", p. 11. 


\section{E. Invented Popular Prayers in Rajab and Sha ${ }^{c} b a ̄ n$}

In addition to sacrifices and fasting, the popular sanctity of Rajab and Shacban made them the suitable holy months for invented popular prayers with varying structures, functions, and symbolism. The most popular of them are the prayers on the eve of the first Friday of Rajab, called al-raghä $\dot{a} b$ (wishes), and the prayer on the eve of mid-Shában, called al-Alfyya (the millennium) practiced after sunset. ${ }^{62}$ Both prayers were invented for spiritual, psychological, and social reasons. The Raghä íb is a demanding prayer; it acquired its name from the expected wishes fulfilled to those who practice it ${ }^{63}$, as it refers to the desire for great divine rewards ${ }^{64}$, with reference to the Quran, 21: 90, in which the term raghaban encompasses humility, demand, and divine recompense. ${ }^{65}$ With these religious connotations in mind, Rajab and Shacban were the most suitable months for performing these prayers because of their sanctification.

Historically, the Ṣūfì Abū Țālib al-Makkī (d. 386 H/996 AD) in his Qüt al-qulūb, largely quoted by later sources, ${ }^{66}$ was the first who allotted Rajab and Shacbān with specific prayers in the first, fifteenth, and twenty-seventh nights of both months. He quoted al-Hasan Ibn Ali Ibn Abī Țâlib, who mentioned that the Companions of the Prophet used to pray on the eve of mid-Shacbān collectively. ${ }^{67}$ However, al-Makkī'in the mid-fourth century Hijri/ ninth AD, and al-Ṭurțūshìs (d. 520 H/1126 $\mathrm{AD}$ ) in the early sixth $\mathrm{H} /$ twelfth $\mathrm{AD}$ century, descriptions of these invented prayers revealed that they were in their formative period; they

${ }^{62}$ Shi'i scholars consider sunset prayer as a way of thanking God for gifting us the soul (nafs), which intermediates between the light of the intellect and the darkness of nature. Evening prayer is a medium of contemplating about the Imams who withstand the Prophet's message when the darkness of ignorance spreads over. Katz, Prayer in Islamic Thought and Practice, p. 115. See, e.g., Ibid., pp. 155-6. for the mystic interpretation of the acts of prayer according to the $13^{\text {th }}$ century Andalusian Șūfî Ibn cArabī.

63 Shāmah, al-Bă ith, p. 63.

${ }^{64}$ Muḥammad ibn Aḥmad Azhurī, Tahdhīb al-lughah, vol. 8, ed. by Maḥmūd (Egypt: Misriyya), p. 121.

65 Manẓūr, Lisān al-'Arab, vol. 1, p. 189.

66 al-Ghazzali, Ibya' ulum al-din, vol. 1 (Cairo: Dar al-Tauzi', 1997), p. 194; AlJaylani, Al-ghunyah li talibi tariq al-haq 'az wa jal, vol. 1, p. 174.

67 Syeikh Abu Talib Al-Makki, Qüt al-qulüb, vol. 1 (Beirut: Al-Kutub al-'ilmiyya, 2005), pp. 93-4. 
have not acquired their final structures and terminologies. By the sixth century Hijri, the terminology was almost canonized with reference to the alleged hadīth, "Rajab is the month of God, Shacbān is my month, and Ramadān is the month of my people... but do not ignore the first Friday eve in Rajab. It is a night named by the angels: raghă ${ }^{-} i b "{ }^{\prime 68}$ This hadīth indicates that salät al-raghä áib is the prayer on eve of the first Friday in Rajab, whereas that on mid-Shacbān is canonized as the alfiyya, with reference to its structure.

The raghā $\bar{i}$ ib popular consists of 12 rakc $^{c} a$. Each rak $a$ comprises the recitation of the First Chapter of the Quran (Fätiha), Chapter 97 (Qadar) three times, and Chapter 112 (Ikhläs) 12 times. It ends by glorifying the Prophet 70 times and praising God (subbūh, quddūs, rabbu al-malā'kati wa al-rüh) 70 times, ${ }^{69}$ followed by a long supplication of praise, mercy, and forgiveness, and ends by asking wishes. ${ }^{70}$ The prayer on the eve of mid-Rajab consists of four rakca. In each rak a, the worshiper recites the First Chapter of the Quran (Fätiha), Chapter 112 (Ikhläs) 20 times, the Chapter 113 (Falaq) three times, and the Chapter 114 (al-Nās) three times. He, then, prays on the Prophet for 10 times and to praises God, unifies Him and glorifies Him for 30 times. Anyone who performs these prayers, the hadith says

God will order one thousand angels to write his deeds hasanāt and plant for him trees in the paradise. God will forgive him any sin he committed...

${ }^{68}$ Ibid., vol. 1, p. 93; Aț-Ṭurțūšī, Al-ḩawädiṭ wa-ăl-bidac, p. 267; Shāmah, al-Bāicith, p. 57; al-Ghazzali, Ibya' ulum al-din, vol. 1, p. 194; Al-Jaylani, Al-ghunyah li talibi tariq al-haq 'az. wa jal, vol. 1, pp. 181-92; Ibn al-Jawzī, Al-Mawdü'ät, vol. 1, pp. 123-7.

69 Reciting Godıs names (dhikr) is a common practice all over the Muslim world. It is "intended to intensify the remembrance of God, and, through that, foster an ongoing sense of closeness to Him". In Indonesia, they take the form of lengthy recitations of the Ninety-Nine Beautiful Names of God, and also the repetition of short phrases from the Qur'an. In Sufi orders, the chosen passage is chanted using specified breathing patterns and greater or lesser movement of the body to become highly rhythmical and even, in some usages, ecstatic. Arif Zamhari and Julia Day Howell, 'Taking Sufism to the streets: 'Majelis zikir' and 'majelis salawat' as new venues for popular Islamic piety in Indonesia", RIMA: Review of Indonesian and Malaysian Affairs, vol. 46, no. 2 (2012), p. 49.

70 Al-Jaylani, Al-ghunyah li talibi tariq al-haq 'az wa jal, vol. 1, pp. 181-2; Ibn al-Jawzī, Al-Mawdū'āt, vol. 1, p. 125; Muhammad ibn Ali Al-Shawakānī, Al-Fawāì almajmù'a, ed. by al-Yamānī (Beirut: Al-Kutub al-'ilmiyya, 1960), p. 106. 
He will give him for each letter he recites in this prayer 700 deeds, and for each prostration and bow down, he earns 10 palaces in paradise made of green aquamarine (zabarjad), and he will be given 10 cities in heaven, each made of red sapphire (yäqüt). ${ }^{71}$

Moreover, sources mentioned two other prayers. The first prayer consists of the recitation of the First Chapter (Fatiha) once and the Verse of the Throne (āyat al-kursi) for 100 times, in the first part of the prayer, and the First Chapter (Fätiba), then, Chapter 112 (Ikbläs) for a 100 times, in the second rake $a^{\text {" }} .^{72}$ The second, on the eve of the $27^{\text {th }}$ night of Rajab, comprises four $r a k^{c} a$. In each $r a k^{c} a$, the worshipper recites the First Chapter of Quran (Fätịa), Chapter 113 (Falaq), Chapter 114 (al-Nās), Chapter 97 (Qadar), and Chapter 112 (Ikhlāṣ) for 50 times. $^{73}$

Contrary to Rajab prayers, which vary significantly regarding structure, the most popular prayer of Shaban is that of the eve of its midmonth. Sources reported a sort of consensus concerning its time, but they differed widely concerning its structure. Famous among these is the alfiyya (Millennium) as it consists of $100 \mathrm{rak}^{c} a$; in each rakc $a$, the First Chapter (Fätiba) should be recited once, and the Chapter 112 (al-Tkbläs) 10 times. The reward associated with it is remarkable. ${ }^{74}$

The supplications following these prayers consist of glorifying and praising an Almighty, Forgiving, Merciful God who rewards without limits. They are articulated on asking for divine forgiveness and mercy and satisfying humanly needs. ${ }^{75}$ By these supplications popular Muslims linguistically formulate and nurture their divine worlds. Therefore, popular religious culture becomes a modality for expressing people's social, spiritual, and psychological needs and interests. Take for example the housing-rewards of these prayers. They reflect images of magnificent castles of sapphires and aquamarine similar to Persian castles depicted

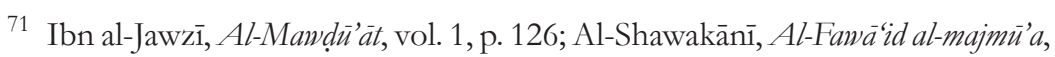
p. 107 no. 50 .

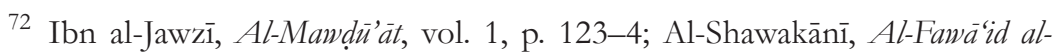
majmü'a, p. 105 no. 47.

73 Al-Jaylani, Al-ghunyah li talibi tariq al-haq 'az wa jal, vol. 1, p. 182.

${ }^{74}$ Ibid., 1: 192; Ibn al-Jawzī, Al-Mawdèn'āt, vol. 1, p. 126; Al-Shawakānī, Al-Fawà̄id al-majmü'a, p. 108 no. 50; Al-Makki, Qüt al-qulüb, vol. 1, p. 94.

75 Al-Jaylani, Al-ghunyah li talibi tariq al-haq 'az wa jal, vol. 1, p. 180. 
in Arabic poetry. ${ }^{76}$

Muslim scholars referred to the Quran, the Prophetic Hadiths and the consensus of Early Generations, either to legitimize or to denounce these rituals. Șūfì scholars interpretatively referred to Quran, 44:1-4 to support the sanctity of the eve of mid-Sha'ban as the 'blessed night' mentioned in these verses. Al-Jaylāni attributed such an interpretation to 'Ikrima, the disciple of Ibn ${ }^{\mathrm{c}}$ Abbās. ${ }^{77}$ Sunni scholars disagree with this opinion, as a strategy to diminish these invented prayers. They considered that this interpretation of ${ }^{~} \mathrm{I}$ krima lacks proof. ${ }^{78}$ Furthermore, ${ }^{\mathrm{C}} \mathrm{Ikrima}$, for them, was an unreliable source of Islamic knowledge, ${ }^{79}$ as he was blamed for propagating Khārijism, ${ }^{80}$ which is considered a heretical sect.

Moreover, Șūfī scholars relied on the authority of early generations of Islam to support these invented rituals. ${ }^{81}$ Al-Makki referred to alHasan al-Bașrī, who reported that 30 of the Companions of the Prophet supported the prayer of mid-Shacban. ${ }^{82}$ Sunni scholars also disagree with these proofs. Al-Ṭuttūshī referred to the consensus of the early Companions of the Prophet and Muslim scholars who considered the blessed night mentioned in Quran, 44:1-4, is the night of al-qadar, not that of mid-Shacban. ${ }^{83}$ Ibn al- ${ }^{\mathrm{c}} \mathrm{Arabi}$ (d. $543 \mathrm{H} / 1148$ AD) supported this opinion claiming that there is no reliable report concerning the virtues of the night of mid-Shábann ${ }^{84}$, a view affirmed by Ibn al-Fattāl (d. 508

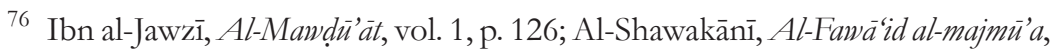
p. 107 no. 50 .

77 Al-Jaylani, Al-ghunyah li talibi tariq al-haq 'az wa jal, vol. 1, p. 191.

78 Fakhr al-Dīn Muhammad ibn 'Umar Rāzī, Mafätīh al-ghayb al-mushtabir bi-alTafsì al-kabir, vol. 27 (Cairo: al-Mațba'a al-Mișriyya, 1983), pp. 237-8.

79 Muhammad ibn Aḥmad Dhahabī, Tärīkh al-Isläm wa-wafayāt al-mashāhìr waal-ałàm, vol. 4 (Cairo: Maktabat al-Qudsī, 1948), p. 160.

80 Yūsuf ibn 'Abd Allāh Ibn 'Abd al-Barr, al-Istidhkērr, vol. 2 (Beirut: Dār alKutub al-'Ilmīyah, 2000), p. 33.

81 Al-Jaylānī, Al-Ghunya, vol. 1, p. 179.Al-Jaylani, Al-ghunyah li talibi tariq al-haq 'ar wa jal, vol. 1, p. 179.

82 Al-Makki, Qūt al-qulüb, vol. 1, p. 93.

83 Aț-Ṭurțūšì, Al-hawāàdit wa-ăl-bida', p. 262.

84 Abu Bakr Muhammad Ibn Abd Allah Ibn Al-Arabi, Abkam al-Qur'an, vol. 4, ed. by al-Bijāwī (Beirut: Al-Jīl), p. 1690. 
H/ 1114AD), who reported that Imām al-Riḍā denied it any support. ${ }^{85}$ Hadìth corpora include many Prophetic speeches concerning both prayers of Rajab and Shacbān. Muslim scholars resorted to the science of the criticism of the chain of transmitters of the badith ('ilm al-jarbs wa al-tac $a_{i}$ ) to demonstrate that most of the chains of narrators of the hadiths legitimizing these invented prayers are either broken, interrupted, or forged as they were reported on the authority of people who had never meat each other. However, their views, in this regard, vary widely. Two well-known ḩadiths legitimizing these invented prayers were largely discussed. ${ }^{86}$

The first Hadith: "Rajab is the month of Allah, Sha'bann is my month and Ramadann is my people's month...but do not ignore the first Friday night in Rajab. It is a night named by the angels: the Raghäib ..." ${ }^{87}$ In his critique of the chain of transmitters of this Hadith, Abū Shāma noted that one of the narrators, Ibn Jahdam (d. 414 H/1023 AD), was accused of forging hadith, ${ }^{88}$ and so did Ibn al-Jawz $\overline{1}^{-89}$ and Al-Dhahabī. ${ }^{90}$ The second badith: "Pray on the eve of mid-Sha'ban and fast on its day. The Almighty God descends by sunset to the lowest heaven and says, I forgive anyone who asks forgiveness and I cure anyone who asks for healing, so on and

${ }^{85}$ Fattal al-Nisaburi, Rawdat al-waïzin., vol. 2, p. 320 no. 1243.

86 For other Hadiths and their criticism see Muhammad ibn Yazīd Ibn Mājah, Al-Sunan, vol. 1 (Beirut: Dār al-Nawādir, 2013), p. 440 no. 1389; Shāmah, al-Bāicth, p. 55; Aḥmad ibn 'Alī Ibn Hajar al-'Asqalānī, Tahdhìb al-tahdhīb, vol. 4 (Beirut: Dār Șādir, 1968), p. 446 no. 776; Aḥmad ibn 'Alī Ibn Hajar al-'Asqalānī, Tahdhīb al-tabdhìb, vol. 5 (Beirut: Dār Șādir, 1968), p. 362 no. 625; Aḥmad ibn 'Alī Ibn Hajar al-'Asqalānī, Tahdhìb al-tabdhīb, vol. 7 (Beirut: Dār Șādir, 1968), p. 182 no. 351; Aḥmad ibn 'Alī Ibn Hajar al-'Asqalānī, Tahdhìb al-tahdhīb, vol. 9 (Beirut: Dār Șādir, 1968), p. 196 no. 365; Aḥmad ibn 'Alī Ibn Hajar al-'Asqalānī, Tahdhīb al-tahdhīb, vol. 11 (Beirut: Dār Șādir, 1968), p. 196 no. 365; ibid., 11: 268-70 no. 539; Al-Jaylani, Al-ghunyah li talibi tariq al-haq 'az wa jal, vol. 1, p. 190-1; Muhammad ibn Aḥmad Qurțubī;, al-Jāmi' li-ạ̣kam al-Qur'ān, vol. 16 (Cairo: Al-Mișriyya, 1964), p. 127.

87 Al-Jaylani, Al-ghunyah li talibi tariq al-haq 'az wa jal, vol. 1, p. 192; Ibn al-Jawzī, Al-Mawdü'àt, vol. 1, p. 125; Shāmah, al-Bā'ith, p. 63.

88 Shāmah, al-Bāith, p. 63.

89 Ibn al-Jawzī, Al-Mawdü'ā't, vol. 1, p. 125.

90 Dhahabī, Mì̄àn al-ítidäl, vol. 4, p. 124 no. 5897. 
so forth until sunrise". ${ }^{11}$ For Ibn Māja (d. 273 H/ 886 AD), the chain of narrators of this hadith is weak because Abu Subra (lived in the $1^{\text {st }}$ century $\mathrm{H} / 7^{\text {th }} \mathrm{AD}$ ), was accused of forging hadiths. ${ }^{92}$ However, hadith scholars disagree about the character of these reporters and the degree of their trustworthiness, and thus, their endeavor to denounce these invented prayers is not thoroughly convincing. For example, Ibn Hajar declared that Ibn Jahḍam was "trustworthy, veracious, learned, pious, well-treating and of good knowledge" ${ }^{93}$, and so did Ibn Hibban for Abū Subra. ${ }^{94}$

In another step, Muslim scholars criticized the books that mentioned the virtues of Rajab, such as Razīn Ibn Mu'āwia's Tajrìd al-șiḩāh and alGhazālì’s Ibya a' ulüm al-dìn. ${ }^{95}$ For Abū Shāma, the hadìths of the virtues of Rajab and Sha'bān have no religious bases "although they were mentioned in these books". ${ }^{96} \mathrm{Al}$-Shawakānī affirmed this view and blamed Razīn Ibn $\mathrm{Mu}^{\mathrm{c} a \bar{a} w i a}$ for including forged hadiths in his book. ${ }^{97}$ Thus, Muslim scholars considered the prayer of al-raghäib "a reprehensible innovation that signals misguidance and ignorance and is full of clear evils". ${ }^{98} \mathrm{Al}-$ Wansharīsī (d. $914 \mathrm{H} / 1509$ AD) reported that al-raghä ícb prayer was classified as an "ugly, reprehensible heresy that should be discontinued. The governor should prevent people from practicing it. Establishing it throughout the Islamic world should not be a rule to follow". ${ }^{99}$

91 Ibn Mājah, Al-Sunan, vol. 1, p. 444 no. 1388; Aț-Ṭurțūšī, Al-ḥawādit wa-ăl-bidac, p. 161; Al-Shawakānī, Al-Fawa'id al-majmù'a, p. 51.

92 Shāmah, al-Bāith, p. 55.

93 Abu al-Fadl Ahmad ibn Ali Ibn Hajar, Lisān al-mīàn (Beirut: al-A'lamì li-lMaṭbūāt, 1971) no 641.

94 Aḥmad ibn 'Alī Ibn Ḥajar al-'Asqalānī, Tahdhīb al-tahdhīb, vol. 12 (Beirut: Dār Ṣādir, 1968), p. 105 no.483.

95 Al-Shawakānī, Al-Fawāiid al-majmü'a, p. 49; 'Abd al-Ḥayy ibn Aḥmad Ibn al-'Imād, Shadharāt al-dhahab fì akhbār man dhahab, vol. 3, ed. by al-Arnāūṭ (Beirut: alMaktab al-Tijārī lil-Ṭibā'ah wa-al-Nashr wa-al-Tawzī', 1966), p. 106.

96 Shāmah, al-Bāith, p. 67.

97 Ibid., p. 48.

98 Al-Nawawī, Sharh Șah̄ị Muslim, 8: 20; Shāmah, al-Bāith, p. 75.

99 Aḥmad ibn Yahyá Wansharīsī, al-Mi'yār al-mu'rib wa-al-jāmi' al-mughrib 'an fatāwá abl Ifriquìah wa-al-Andalus wa-al-Maghrib, vol. 1, ed. by Muhammad. Hajjīi (al-Rabāṭ: Wizārat al-Awqāf wa-al-Shu'ūn al-Islāmīyah lil-Mamlakah al-Maghribìyah, 1981), p. 300; Aḥmad ibn Yahyá Wansharīsī, al-Míyār al-mu'rib wa-al-jāmi' al-mughrib 'an fatāwá abl 


\section{F. Popular Ritual as a Socio-Cultural Festivity}

Despite these efforts to delegitimize these invented popular prayers, they have continued to be collectively celebrated with joyous festivity, even much more than the official forms of worship. ${ }^{100}$ For Muslim scholars, the collective celebration of these prayers, their rituality (mawsim wa shitâr, in Abū Shāma's words), and the symbolism associated with them, as elements of 'popular religion' in Jacques Waardenburg 's term, ${ }^{101}$ are the significant components that merit their classification as reprehensible innovations. ${ }^{102}$ The celebration of these prayers was accompanied with marvelous decorations of mosques and shrines, blazing fires, and burning incense ${ }^{103}$; a phenomenon characterizing Sufism all over the Muslim world, as it absorbed different cultural and mystical beliefs and practices. ${ }^{104}$ Muslim scholars considered these elements "as borrowings from other religions, in particular from paganism as it existed before Islam in Arabia and elsewhere, and from Eastern Christianity with its rituals, feasts, and veneration of saints" ${ }^{\prime 105}$, as well as ancient Persian religions and culture. Abū Shāma interpreted blazing fire in mosques and praying in front of it as a worship of the holy fire of the Magus. ${ }^{106}$ These prayers and the festivities associated with them, in his view, reflect Persian religious elements that have invaded Islam and significantly distorted it. ${ }^{107}$

In addition to the origin of these festivities, Muslim scholars denounced the social conduct of Muslims such as the mixing of men and

Ifrīquiyah wa-al-Andalus wa-al-Maghrib, vol. 2, ed. by Muhammad. Hajjī (al-Rabāṭ: Wizārat al-Awqāf wa-al-Shu'ūn al-Islāmīyah lil-Mamlakah al-Maghribīyah, 1981), pp. 508-9.

100 Muḥammad ibn Muhammad Ibn al-Hāij, Madkhal al-shar'al-sharif, vol. 4 (Cairo: al-Mațba'a al-Mișriyya, 1929), p. 260.

101 Jacques Waardenburg, Islam: Historical, Social and Political Perspectives (Berlin: De Gruyter, 2002), p. 85.

102 Shāmah, al-Bä́ith, p. 67. The collective celebration of invocation, praising God, and collective prayers are widespread in the Muslim world. See for example. Zamhari and Howell, "Taking Sufism to the Streets", p. 49.

103 al-Hāajj, Madkhal al-shar'al-sharif, vol. 4, p. 257.

104 Andrew N. Weintraub (ed.), Islam and Popular Culture in Indonesia and Malaysia (New York: Routledge, 2011), p. 3.

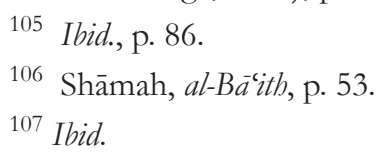


women during the celebration of the festivities related to these prayers (al-fusūq wa al-'isyann wa ikhtilät al-rijäl bi al-nisāa $)^{108}$; a fact that challenged the normative, canonical vision of strict scholars. Collective establishing of these prayers, male-female mixing, and the festivity associated with them, according to this interpretation, are effective symbolic tools of human expression, needs, and desire; these rituals do not only fulfill spiritual and psychological needs but also social and biological desires related to pleasure, ${ }^{109}$ despite the fact that the automatic reflect of desire and pleasure on prayers echoes a misunderstanding of the function of the sacred in human culture according to Besnard. ${ }^{110}$

On the other hand, the socialization of these prayers made them acts of empowerment. Marion Holmes Katz's 'royal audience model of prayer' is significant in this regard. ${ }^{111}$ Political regimes felt the importance of these prayers and the congregations related to them, so they used them to reinforce social hierarchies and legitimize monarchical powers by enhancing the value of submission to God, and thus, to the ruler, as His deputy (khalifa). Muslim rulers and governors used to sit in mosques' courtyards to judge people, punish the guilty, and show mercy on smaller crimes on the eve of mid-Shacban, which "reflect[s] the idea of God's judgment in this month or during this night". ${ }^{112}$ For this reason, Muslim governors tolerated with these rituals. The case of Imām of Damascus, Ibn cAbd al-Salām (d. 660 H/ 1262 AD) is revealing in this regard. He sought to invalidate the prayer of al-raghä'ib, and wrote a treatise on the subject. However, the Sultan compelled him to admit it and to write on its approval. ${ }^{113}$ On political pressure, he issued a fatwa acknowledging the

108 Ibid., p. 51.

109 Mabrouk Mansouri, "Cynophagy, Homosexuality and Anthropophagy in Medieval Islamic North Africa as Signs of Hospitality", The Journal of North African Studies, vol. 20, no. 2 (2015), pp. 128-42.

110 Albert-Marie Besnard, "Prière et Contemplation", Encyclopadia Universalis, vol. 18 (Paris: Encyclopaedia Universalis France, 2016), p. 975.

${ }^{111}$.Katz, Prayer in Islamic Thought and Practice, pp. 92-102.

112 Kister, “'Sha'bān Is My Month...’: A Study of an Early Tradition”, pp. 33-4.

113 Shāmah, al-Bäith, pp. 32-3; al-Ḥāji, Madkhal al-shar'al-sharif, vol. 4, p. 280; Kister, "Rajab Is the Month of God.' A Study in the Persistence of an Early Tradition", p. 212. 
virtue of the night of mid-Sha ban and establishing of prayers individually. ${ }^{114}$ Popular prayers are collective acts of adoration and remembrance of God that permit Man to spiritually perceive a sense of his existence. Prayer in Islam comprises verbal and nonverbal signifiers, ${ }^{115}$ each symbolizing the encounter between humans and the divine to achieve lowliness and submission in front of the world of God. Muslim scholars emphasized the spiritual and therapeutic character of prayers as an effective medical remedy for the body and soul. ${ }^{116}$ In the Șüfî realm, prayer is a medium whereby Man spiritually communicates with God. ${ }^{117}$ However, beyond the psycho-religious motivations of these invented prayers as acts of subservience, submissiveness, and humiliation to God, their sociocultural manifestations make them emblems of socializing acts of Islamic rituals. Muslims dialogize their emotions and need with themselves, their communities, and the supreme God and ask Him forgiveness, prosperity and victory over their enemies. Interestingly, invented prayers could be seen as a defensive strategy of Muslims against their enemies. One of the tasks the Angeles are asked to perform for these prayers performers, says a Hadith attributed to the Prophet: God will send him 20 angels to defend him against his enemies. ${ }^{118}$

Beyond the collective celebration of these festivities, their symbolic decoration, and the promise of mystical experience is the belief in an overwhelming divine world set forth to satisfy worldly and Hereafter human needs. The analysis showed that these invented popular rituals

114 .Shāmah, al-Bä'ith, p. 67.

115 .Katz, Prayer in Islamic Thought and Practice, pp. 98-9.

116 Ibn Qayyim al-Jawziyya, Zād al-ma'àd fì hadì Khayr al-'Tbād, vol. 4, ed. by M. Baltājīi (Beirut: al-Maktaba al-cAșriyya, 2007), p. 533.

117 See, e.g. Al-Ghazālī, Inner Dimensions of Islamic Worship, trans. by Muhtar Holland (Leicester: The Islamic Foundation, 1983); Muhyi al-Din Ibn al-Arabi, On the Mysteries of Purification and Formal Prayer, ed. by Aisha Bewley (Chicago: Kazi Publications, Inc., 2009).For the spiritual and symbolic dimensions of prayer and Islamic ritual in general see, e.g.).Constance E. Padwick, Muslim Devotions: A Study of Prayer-Manuals in Common Use (Oxford Rockport, MA: Oneworld Publications, 1996); Annemarie Schimmel, Mystical Dimensions of Islam (Chapel Hill: The University of North Carolina Press, 1975); Andrew Rippin, Muslims: Their Religious Beliefs and Practices (London: Routledge, 2001).

118 Ibn al-Jawzī, Al-Mawdü'ät, vol. 1, p. 128. 
assumed various functions; they were tokens of gratitude, demands for forgiveness, calls to protection from enemies, and a reaction over tyranny. Consequently, "local religious festivities have significance besides the official feasts of normative Islam". ${ }^{119}$

From a sociocultural point of view, religion offers semiotic frameworks to individuals and groups. Individuals who disguise these semiotic tools may utilize them as assets empowering them to strengthen their sense of belonging to communities and improve the externalization of their emotions, activities, and thoughts. Subsequently, invented rituals, and religion in general, can be used "to support dialogical processes in individuals and groups, to facilitate their dealing with the many mysteries of daily life as well as to apprehend deeper individual and social ruptures". ${ }^{120}$ Among the many mysteries that the period of the widespread of these invented rituals witnessed, and remained unfathomable for medieval Muslims, are astrological events, epidemics, diseases, and disasters interpreted as signs of God's wrath ${ }^{121}$, so Muslims exaggerated in worship and invented new rituals to satisfy Him. Moreover, many geological and astrological events at that time were attributed to the divine. For example, in 582 Hijri (1186 AD), the astrologers claimed that the "world will be ruined by a wind flood (tüfän al-rīh) in Shacbān when the six planets would meet in the Libra (burj al-mīanan)". ${ }^{122}$ In 599 Hijri (1203 AD), "the stars outraged in the sky east and west and spread like locusts blown left and right till down. People were annoyed and afraid. They multiplied their supplication asking for God's mercy'. ${ }^{123}$ In 645 Hijri (1247 AD), a great fire blazed through Medina. People deemed it a sign of the end of the world ('alämät al-säca). ${ }^{124}$ Muslims interpreted these phenomena regarding the corruption mentioned in Quran, 30:41. Subsequently, "people repented,

119 Waardenburg, Islam: Historical, Social and Political Perspectives, p. 67.

120 Baucal and Zittoun, "Religion as Dialogical Resource", p. 217.

121 Ibn al-'Imād, Shadharāt al-dhahab, vol. 3, p. 192.

122 'Abd al-Hayy ibn Aḥmad Ibn al-'Imād, Shadharät al-dhahab fì akhbār man dhahab, vol. 4, ed. by al-Arnāūṭ (Beirut: al-Maktab al-Tijārī lil-Ṭibā'ah wa-al-Nashr wa-al-Tawzì', 1966), p. 273.

123 Ibid., vol. 4, p. 388.

124 'Abd al-Hayy ibn Aḥmad Ibn al-'Imād, Shadharät al-dhahab fì akhbār man dhahab, vol. 5, ed. by al-Arnāūṭ (Beirut: al-Maktab al-Tijārī lil-Ṭibā'ah wa-al-Nashr wa-al-Tawzí', 1966), p. 263. 
poured liquor, broke musical instruments, gave most of their money for charity, and secluded in mosques". ${ }^{125}$ Muslims thought that the world was ending and that resurrection would soon occur. To save themselves and ensure their welcome to paradise, they repented and exaggerated in worship to satisfy God.

Astonishing, the celebration of these popular invented rituals, mainly prayers and fasting, spread remarkably in the last three decades in the Arab world. The issue of their overwhelming emergence needs further scrutiny. However, they could be interpreted as a reaction to tyranny, corruption, turmoil and sociopsychological unrest devastating the Arab world. This very reaction is grounded the medieval Sufi perceptions of holy time and God's response to human supplication, which goes back to the pre-Islamic period. Sufis have emphasized the idea that Rajab was correlated with the holy response to the invocation of the oppressed, on the one hand, and doubling of the oppressor's punishment on the other. ${ }^{126}$ In al-Jaylānîs words, "The supplication against the oppressor and the tyrant is receivable by God amid the month of Rajab. Pre-Islamic people used to postpone their invocations against their oppressors to the month of Rajab". ${ }^{127}$ Remarkably, some popular rituals of Rajab and Shacban nowadays are followed by supplications reflecting these collective concerns. A socio-psychological analysis may explain the continuity of such a vision and reveal psycho-spiritual reasons underneath. The continuous emphasis on the reprehensibility of these invented rituals in each Friday sermon in Rajab and Shában, and the continuous cyber raids led by 'puritan' scholars failed to eliminate them; a fact that needs further multi-fold examination.

\section{G. Concluding Remarks}

The holiness of Rajab and Shacbān in Islamic popular culture expresses a complex whole of perceptions and visions regarding time, space and rituality. Invented rituals in Islam, despite being condemned by official scholars, have enigmatically manifested inner and outer religious

125 Ibn al-'Imād, Shadharāt al-dhahab, vol. 3, p. 279; Ibn al-'Imād, Shadharāt aldhahab, vol. 4, p. 328.

126 Al-Jaylani, Al-ghunyah li talibi tariq al-haq 'az, wa jal, vol. 1, p. 184.

127 Muhammad ibn Ismā̄î̀ Șan'ānī, Tafsìr, vol. 7 (Beirut: Al-Kutub, 1998), p. 32. 
experiences of the individual and the group to which he belonged. They were, thus, means of socialization and orchestration of Islamic rituality. These invented collective rituals and the festivities associated with them express, in this sociocultural perspective, a socialization of the inner and collective experience of religiosity. While 'puritan' Muslims took it as their religious duty to diminish them, their endeavor failed because they underestimated the multi-fold functions these invented rituals have been performing for ordinary Muslims. Their scholastic tools have proved invalid in delegitimizing them.

Accordingly, the popular sacrifices go beyond the phenomenal act of charity and blessings; they are sociocultural rites full of expressivity and symbolism, on one hand, and a collective festivity that embedded a vision of time, space and things on the other. They are religious techniques establishing and regulating in-tribal and inter-tribal relationships. While invented fasting remains in the closed circle of privatization, daylong divine chanting, Holy Names reciting, and crowd fast-breaking are collectivizing manifestations of this experience. As for prayers, they are emblematic tools of socialization echoing a re-evaluation of holy time and space on the light of inherited individual and collective cultural settings according to spiritual, psychological and social human needs related to the worldly and divine realms.

An in-depth analysis of the various cultural structures and framing features of popular imagination from an anthropological stand may help uncover the vibrancy of these rituals and shed light on the manner through which innovated forms of worship respond to ordinary people's religious, psychological, and spiritual needs. Deciphering the components and background of popular rituals in Islam will be a significant key to understanding the cultural metamorphosis governing Islamic culture, and a way to grasp the shapes of official Islamic culture itself. Besides anthropology, Islamic studies have to examine what impact spiritual experiences invented rituals had on people's lives and their vision of the divine. Psychology of religion and sociocultural psychology are revealing in this regard. 


\section{BIBLIOGRAPHY}

Al-Ghazālī, Inner Dimensions of Islamic Worship, trans. by Muhtar Holland, Leicester: The Islamic Foundation, 1983.

al-Ghazzali, Ibya' ulum al-din, vol. 1, Cairo: Dar al-Tauzi', 1997.

Al-Jaylani, Abd. Al-Qadir, Al-ghunyah li talibi tariq al-haq 'az wa jal, vol. 1, Beirut: Dar al-Kotob al-'IImiyah, 2003.

Al-Makki, Syeikh Abu Talib, Qüt al-qulūb, vol. 1, Beirut: Al-Kutub al'ilmiyya, 2005.

Al-Nawawī, Sharḥ Șahị̣̄ Muslim, vol. 8, Cairo: Maṭbacat al-Hijāzī.

Al-Shawakān̄ī, Muhammad ibn Ali, Al-Fawāid al-majmū'a, ed. by alYamān̄i, Beirut: Al-Kutub al-'ilmiyya, 1960.

al-Arabi, Muhyi al-Din Ibn, On the Mysteries of Purification and Formal Prayer, ed. by Aisha Bewley, Chicago: Kazi Publications, Inc., 2009.

Asad, Talal (ed.), Anthropology \& the Colonial Encounter, Amherst, NY: Humanity Books, 1973.

----, The Idea of an Anthropology of Islam, Washington: Center for Contemporary Arab Studies, Georgetown University, 1986.

Aț-Ṭurțūšs̄i, Muhammad Ibn al-Walīd, Al-ḅawādit wa-ăl-bida', ed. by 'Abd al-Ma'īd Turkī, Beirut: Al-Gharb al-Islāmī, 1990.

Azhurī, Muhammad ibn Aḥmad, Tahdhïb al-lughah, vol. 2, ed. by Maḥmūd, Egypt: Misriyya.

----, Tahdhïb al-lughah, vol. 8, ed. by Maḥmūd, Egypt: Misriyya.

al-Baghdādī, Abū Bakr Aḥmad ibn 'Alī Khațīb, Tarikh Baghdad., vol. 8, Beirut: Dar al-Kitab al-'Arabi, 1966.

Bakrī, Abd al-'Azīz, Al-Masälike wa al-Mamälik, vol. 2, ed. by Van Lioven and A. Feery, Tunisia: Al-'Arabiyya, 1968.

Baucal, Aleksandar and Tania Zittoun, "Religion as Dialogical Resource: A Socio-cultural Approach", Integrative Psychological and Behavioral Science, vol. 47, no. 2, 2013, pp. 207-19 [http://dx.doi.org/10.1007/ s12124-013-9229-z].

Bello, María Isabel Fierro, Heterodoxia en al-Andalus Durante el Periodo Omeya, Madrid: Instituto Hispano-Árabe de Cultura, 1987. 
Besnard, Albert-Marie, "Prière et Contemplation", Encyclopadia Universalis, vol. 18, Paris: Encyclopaedia universalis France, 2016.

Brunschvig, Robert, "Le culte et le temps dans l'islam classique", in Études d'islamologie, vol. 1, Paris: G.-P. Maisonneuve et Larose, 1976.

Dhahabī, Muhammad ibn Aḥmad, Tārīkh al-Isläm wa-wafayāt al-mashāhìr wa-al-ààm, vol. 4, Cairo: Maktabat al-Qudsī, 1948.

----, Mì̃àn al-iłtidàl, vol. 4, ed. by 'Ali Muhammad Bajawi, Cairo: Dar Ihya' al-Kutub al-'Arabiyah, 1962.

Fattal al-Nisaburi, Muhammad ibn al-Hasan, Rawdat al-waï̌in., vol. 2, ed. by Gh. Majīīī and M. Farjīi, Qum: Dalīl Mā, 1961.

Geertz, Clifford, Islam Observed: Religious Development in Morocco and Indonesia, Chicago: University of Chicago Press, 1971.

----, "Religion as a Cultural System", in Anthropological Approaches to the Study of Religion, ed. by Michael Banton, London: Routledge, 2004.

Gennep, Arnold van, The Rites of Passage, Chicago: University Of Chicago Press, 1972.

Goitein, Shelomo Dov, "Ramadan, The Muslim Month Of Fasting, Its Early Development And Religious Meaning", in Studies in Islamic History and Institutions, Leiden: Brill, 1968, pp. 90-110.

----, Studies in Islamic History and Institutions, Leiden: Brill, 2010.

Hajar, Abu al-Fadl Ahmad ibn Ali Ibn, Lisān al-mĩāàn, Beirut: al-A'lamī li-l-Maṭbū'āt, 1971.

al-Hāijj, Muḥammad ibn Muḥammad Ibn, Madkhal al-shar'al-sharif, vol. 4, Cairo: al-Mațba’a al-Mișriyya, 1929.

Haythamī, Nūr al-Dīn 'Alī ibn Abī Bakr, Majma' al-zawä̀id wa-manba' alfawàì, vol. 3, Beirut: Al-Kitāb al-Lubnān̄̄, 1967.

Hodgson, Marshall G.S., The Venture of Islam: Conscience and History in a World Civilization, Chicago: University of Chicago Press, 1974.

al-'Asqalānī, Aḥmad ibn 'Alī Ibn Hajar, Tabyin al-'ajab bimà warada fí fadli Rajab, Mișr: Maktabat 'Abd al-Wāḥid al-Tāzī, 1932.

----, Tahdhìb al-tahdhìb, vol. 4, Beirut: Dār Șādir, 1968.

----, Tahdhīb al-tahdhìb, vol. 5, Beirut: Dār Șādir, 1968.

----, Tahdhìb al-tahdhìb, vol. 7, Beirut: Dār Șādir, 1968. 
----, Tahdhīb al-tahdhìb, vol. 9, Beirut: Dār Șādir, 1968.

----, Tahdhìb al-tahdhìb, vol. 11, Beirut: Dār Șādir, 1968.

----, Tahdhīb al-tahdhìb, vol. 12, Beirut: Dār Șādir, 1968.

'Az̄īmābādī, Muhammad Shams al-Haqq, 'Awn al-ma'büd: sharh Sunan Abì Däwüd, vol. 6, Madinah: al-Maktabah al-Salafiyah, 1968.

Ibn Al-Arabi, Abu Bakr Muhammad Ibn Abd Allah, Abkam al-Qur'an, vol. 4, ed. by al-Bijāwī, Beirut: Al-jīl.

Ibn al-Athīr, Majd al-Dīn al-Mubārak ibn Muhammad, al-Nihāya fì gharīb al-ḥadìth wa-al-athar., vol. 2-3, ed. by A. Zāwī and M. Ṭanāhịi, Cairo: Dār Iḥyā’ al-Kutub al-cArabiyya, 1963.

Ibn al-'Imād, 'Abd al-Hayy ibn Aḥmad, Shadharät al-dhahab fi akhbār man dhahab, vol. 3-5, ed. by al-Arnāūț, Beirut: al-Maktab al-Tijārī lilTibā`ah wa-al-Nashr wa-al-Tawzī' 1966.

Ibn al-Jawzī, Abū al-Faraj 'Abd al-Raḥmān ibn 'Alī, Al-Mawdū'āt, vol. 1, Makkah: Al-Maktaba al-Salafiyya, 1966.

Ibn 'Abd al-Barr, Yūsuf ibn 'Abd Allāh, al-Istidhkār, vol. 2, Beirut: Dār al-Kutub al-'Tlmìyah, 2000.

Ibn 'Idhārī, Muhamamad, al-Bayān al-Mugrib, vol. 1, ed. by G.S. Colin and Evariste Lévi-Provençal, Beirut: Dār al-Thaqāfah, 1967.

Ibn Khaldūn, Kitāb al-íbar, vol. 4, Beirut: Dār al-Kitāb al-Lubnānī, 1979.

Ibn Mājah, Muhammad ibn Yazīd, Al-Sunan, vol. 1, Beirut: Dār alNawādir, 2013.

Ibn-Sa'd, Muḥammad, Al-Ṭabaqāt, vol. 7, Beirut: Al-kitāb al-lubnānī, 1957.

al-Jawziyya, Ibn Qayyim, Zād al-ma'ād fì hadì Khayr al-Tbād, vol. 4, ed. by M. Baltàjīi, Beirut: al-Maktaba al-cAșriyya, 2007.

Kathīr, Ismāī’l Ibn, Tafsìr Al-qur'ān, vol. 4, ed. by Sami Salamah, Beirut: Tayba, 1999.

Katz, Marion Holmes, Prayer in Islamic Thought and Practice, Cambridge: Cambridge University Press, 2013.

Kister, M.J., “'Sha 'bān Is My Month...': A Study of an Early Tradition”, in Studia Orientalia Memoriae D.H.Baneth Dedicate, Jerusalem: The Magnes Press \& Institute of Asian and African Studies, 1979, pp. 63-70. 
----, 'Rajab Is the Month of God.' A Study in the Persistence of an Early Tradition", in Studies in Jabiliyya and Early Islam, London: Variorum, 1980, pp. 191-223.

Mansouri, Mabrouk, "Cynophagy, homosexuality and anthropophagy in medieval Islamic North A frica as signs of hospitality", The Journal of North African Studies, vol. 20, no. 2, 2015, pp. 128-42 [http:/ /dx.doi. org/10.1080/13629387.2014.937431].

Manẓūr, Ibn, Lisān al-'Arab, vol. 1, Cairo: Dār al-Șāwī lil-Ṭab“ wa-al-Nashr wa-al-Ta"līf, 2003.

Nakash, Yitzhak, "An Attempt To Trace the Origin of the Rituals of

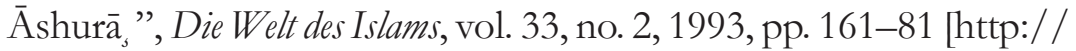
dx.doi.org/10.1163/157006093X00063].

Padwick, Constance E., Muslim Devotions: A Study of Prayer-Manuals in Common Use, Oxford Rockport, MA: Oneworld Publications, 1996.

Qurțubī; Muḥammad ibn Aḥmad, al-Jāmi li-aḅkam al-Qur'ān, vol. 16, Cairo: Al-Mișriyya, 1964.

Rāzī, Fakhr al-Dīn Muhammad ibn 'Umar, Mafätīh al-ghayb al-mushtabir bi-al-Tafsir al-kabir, vol. 27, Cairo: al-Mațba’a al-Mișriyya, 1983.

Rippin, Andrew, Muslims: Their Religious Beliefs and Practices, London: Routledge, 2001.

Said, Edward W., Orientalism, New York: Pantheon Books, 1978.

Șan‘ān̄ī, Muḥammad ibn Ismā̄îl, Tafsìr, vol. 7, Beirut: Al-Kutub, 1998.

Schimmel, Annemarie, Mystical Dimensions of Islam, Chapel Hill: The University of North Carolina Press, 1975.

Shāmah, 'Abd al-Raḥmān ibn Ismāî̀i Abū, al-Bā'ith 'alá inkēr al-bida' waal-ḥawādith, Beirut: al-Fikr, 1992.

al-Tibrīzī, Muḥammad ibn 'Abd Allāh Khaṭīb, Mishkāt al-Mașäbīh, vol. 1, ed. by A. Albānī, Damascus: al-Maktaba al-Islāmiyya.

Tirmidhi, Muhammad ibn 'Isa, Al-Sunan, vol. 3, ed. by 'Uthmān, Beirut: Dar al-Fikr, 1983.

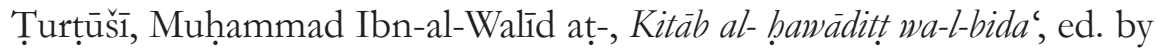
María Isabel Fierro, Madrid: Consejo Superior de Investigaciones Científ., Inst. de Cooperación con el Mundo Árabe, 1993. 
Waardenburg, Jacques, "Official and Popular Religion in Islam":, Social Compass, vol. 25, nos. 3-4, 1978, pp. 315-41 [http://dx.doi.org/10 .1177/003776867802500302].

----, Islam: Historical, Social and Political Perspectives, Berlin: De Gruyter, 2002. Waardenburg, Jean Jacques. and P.H. Vrijhof (eds.), Official and Popular Religion: Analysis of a Theme for Religious Studies, The Hague: Mouton, 1979.

Wagtendonk, K., Fasting in the Koran, Leiden: E.J. Brill, 1968.

Wahib, Ahmad Bunyan, "Being Pious Among Indonesian Salafists", Al-Jami'ab: Journal of Islamic Studies, vol. 55, no. 1, 2017, pp. 1-26 [http://dx.doi.org/10.14421/ajis.2017.551.1-26].

Wansharīsī, Aḥmad ibn Yahyyá, al-Míyār al-mu'rib wa-al-jāmi' al-mughrib 'an fatāwá abl Ifriquiyah wa-al-Andalus wa-al-Maghrib, vol. 1, ed. by Muḥammad. Hajjīi, al-Rabāṭ: Wizārat al-Awqāf wa-al-Shu'ūn alIslāmīyah lil-Mamlakah al-Maghribīyah, 1981.

----, al-Mi'yār al-mu'rib wa-al-jämi' al-mughrib 'an fatāwá abl Ifríqūyah wa-alAndalus wa-al-Maghrib, vol. 2, ed. by Muḥammad. Hajjī, al-Rabāṭ: Wizārat al-Awqāf wa-al-Shu'ūn al-Islāmīyah lil-Mamlakah alMaghribīyah, 1981.

Wazīir al-Andalusī, Muḥammad b. Muḥammad al-, al-Hulal al-sundusiyya fì al-akbār al-Tünisiyya, vol. 1, ed. by Muhammad al-Habīb al-Hīla, Beirut: Al-gharb al-islāmī, 1985.

----, al-Hulal al-sundusiyya fĩ al-akebār al-Tünisiyya, vol. 3, ed. by Muhammad al-Habīb al-Hīla, Beirut: Al-gharb al-islāmī, 1985.

Weintraub, Andrew N. (ed.), Islam and Popular Culture in Indonesia and Malaysia, New York: Routledge, 2011.

Zamhari, Arif and Julia Day Howell, "Taking Sufism to the streets: 'Majelis zikir' and 'majelis salawat' as new venues for popular Islamic piety in Indonesia", RIMA: Review of Indonesian and Malaysian Affairs, vol. 46, no. 2, 2012, p. 47. 
Mabrouk Chibani Mansouri 